\title{
Subcellular Distribution of Ubiquinone and the Content of Ubiquinone and Other Electron Carriers in the Mitochondria Isolated from Tobacco Cultured Cells*
}

\author{
Tsutomu IKeda, Takashi Matsumoto, Takuro KISAKI \\ and Masao NoGUCHI \\ Central Research Institute, The Japan Tobacco and Salt Public Corporation, \\ 6-2, Umegaoka, Midori-ku, Yokohama 227, Japan
}

Received August 8, 1979

\begin{abstract}
The intracellular distribution of UQ in BY-2 cells was examined. The distribution of UQ is well correlated with the distribution of Cyt $\mathrm{c}$ oxidase activity in mitochondria. Mitochondrial preparations from BY-2 cells examined showed a high degree of both coupling and respiratory control. They were further purified by sucrose density gradient centrifugation and UQ and Cyts contents in the purified mitochondria were determined. The UQ and Cyts $(b$ and $c$ ) contents and their molar ratios in BY-2 cell mitochondria are similar to those of mung bean seedling mitochondria.
\end{abstract}

In our previous papers, the relatively high UQ content in cultured tobacco cells $(N$. tabacum L. c.v. BY-2) and some variations in the content in connection with some culture conditions were reported. ${ }^{1 \sim 5)}$ According to our investigations, BY-2 cells contained far more UQ-10 than their parent plants ${ }^{\theta^{\prime}}$ and other higher plant tissues. ${ }^{7}$ The UQ10 content of the cultured BY-2 cells was at a similar level to those of microorganisms which have been reported to contain much UQ-10. ${ }^{8,9)}$ Tanaka et al. reported that mitochondrial UQ was about $25 \%$ of the total UQ and about $65 \%$ of the UQ was localized in the cytoplasm of a hydrocarbon assimilating yeast with a high UQ content. ${ }^{10}$ In plants, UQ has been shown to be localized in mitochondria ${ }^{11,12)}$ and its functional role in the mitochondrial electron transfer chain has been established. ${ }^{13)}$ To investigate the intracellular distribution of UQ in BY-2 cells with an extraordinarily high content and whether or not the molar ratio of UQ to other

* Studies on the Culture Conditions of Higher Plant Cells in Suspension Culture. Part XI, See refs $2 \sim 5$.

Abbreviations: UQ, ubiquinone; Cyt, cytochrome; Fp, flavoprotein; MOPS, 3-(N-morpholino)propanesulfonic acid; BSA, bovine serum albumin; PVP, polyvinylpolypyrrolidone. electron transport components in mitochondria of cultured BY-2 cells is especially high compared with that in other plant mitochondria, some investigations were carried out. The intact mitochondria was isolated from BY-2 cells and further purified by sucrose density gradient centrifugation. The UQ and Cyts contents and the molar ratios were compared to those of similar mitochondria from etiolated mung bean seedlings which are widely used in mitochondrial research. This paper deals with the results.

\section{MATERIALS AND METHODS}

Cultured cells. Cultured tobacco cells (BY-2 cells) were induced from the pith of Nicotiana tabacum L. c.v. BY-2 in 1968 . The culture medium and culture conditions for BY-2 cells were the same as those described in the previous papers. ${ }^{2-\delta)}$ Cultured cells were harvested at 5 days after inoculation, just at the end of the exponential phase of growth. Cultured cells were separated from the culture medium by filtration through filter paper and washed with distilled water.

Mung bean seedlings. Young, etiolated mung bean (Phaseolus aureus) seedlings were obtained from local markets.

Cell fractionation method. Cell fractions were prepared from the protoplasts of BY-2 cells by the following method. A $100 \mathrm{ml}$ culture (about $30 \mathrm{~g} \mathrm{fr}$. wt.), of 5 days duration, was harvested through filter 
paper and washed with distilled water. The cells were resuspended in $100 \mathrm{ml}$ of $2 \%$ Cellulase Onozuka $\mathrm{R}$ $10,0.5 \%$ Macerozyme $R-10,2 \%$ Driselase and $0.5 \mathrm{M}$. mannitol at $\mathrm{pH} 5.8$ and then agitated on a reciprocal shaker at $60 \mathrm{spm}$ for 3 hours at $30^{\circ} \mathrm{C}$ (K. Nakata and H. Oshima, personal communication). The mixture was then centrifuged at $1000 \times g$ for $10 \mathrm{~min}$. The pellet was resuspended in $0.5 \mathrm{M}$ mannitol and recentrifuged to remove the enzymes. The protoplasts (approximately $9 \mathrm{~g} \mathrm{fr}$. wt.) suspended in $40 \mathrm{ml}$ of $20 \mathrm{~mm}$ MOPS buffer ( $\mathrm{pH} 7.4$ ) containing $0.3 \mathrm{M}$ mannitol, $1 \mathrm{mM}$ EDTA, $0.1 \% \mathrm{BSA}$ and $0.05 \%$ cysteine were then ruptured with a Potter-Elvehjem homogenizer. Usually protoplasts were completely broken by five strokes. The ruptured protoplast preparation was centrifuged successively at $250 \times g$ for $10 \mathrm{~min}, 1000 \times g$ for $15 \mathrm{~min}, 10,000 \times g$ for $15 \mathrm{~min}$ and $100,000 \times g$ for $60 \mathrm{~min}$. Each pellet was suspended in a small volume of the grinding medium except that cysteine was omitted.

Preparation of mitochondria. The mitochondria were prepared by the methods of Bonner. ${ }^{14)}$ Typical preparations were started with $120 \sim 140 \mathrm{~g} \mathrm{fr}$. wt. of BY-2 cells $(500 \mathrm{ml}$ culture) which were disrupted with a glass homogenizer (IKEMOTO Co. Ltd.). The grinding medium used ( $200 \mathrm{ml}$ per preparation) consisted of $0.3 \mathrm{~m}$ mannitol, $1 \mathrm{~mm}$ EDTA, $20 \mathrm{~mm}$ MOPS

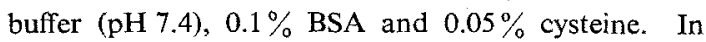
the case of mung bean seedlings, only etiolated stems (hypocotyls) were used for mitochondrial preparation; the roots and cotyledons were removed. The hypocotyls $(100 \mathrm{~g})$ were first chopped into small pieces in the grinding medium $(200 \mathrm{ml})$ with razor blades, and then homogenized with a glass homogenizer. The homogenate was passed through 3 layers of gauze in the case of hypocotyls. The homogenate was centrifuged at $1000 \times g$ for $15 \mathrm{~min}$ to eliminate the cell debris, and then at $10,000 \times g$ for $15 \mathrm{~min}$. The mitochondrial pellet was suspended in a small volume of washing medium identical to the grinding medium except that cysteine was omitted. Following 2 more centrifugations $-250 \times g$ for $10 \mathrm{~min}$, and $6000 \times g$ for 15 min-the mitochondria were collected. The yield of mitochondria was $10 \sim 20 \mathrm{mg}$ protein per preparation. The washed mitochondrial preparations were suspended in a small volume of the washing medium. All operations were carried out between $\mathrm{O}$ and $4^{\circ} \mathrm{C}$.

Purification of mitochondria. Mitochondria were purified on a sucrose gradient. The washed mitochondrial suspension was layered on top of $7 \mathrm{ml}$ of $20 \%$ sucrose (w/w) and $50 \mathrm{ml}$ of a $30 \sim 60 \%(w / w)$ linear sucrose gradient dissolved in $1 \mathrm{mM}$ EDTA (pH 7.4). After centrifugation for $3 \mathrm{hr}$ at $25,000 \mathrm{rpm}(74,766 \times \mathrm{g})$ in a Hitachi 65P ultracentrifuge with an RPS 25-2 rotor, the gradient was collected in $1-\mathrm{ml}$ fractions.
The mitochondrial fractions were collected, combined and diluted slowly with $1 \mathrm{~mm}$ EDTA ( $\mathrm{pH} \mathrm{7.4)} \mathrm{con-}$ taining $5 \%$ sucrose until a sucrose concentration of $20 \%(w / w)$ was achieved. The diluted mitochondria were centrifuged at $10,000 \times g$ for $20 \mathrm{~min}$ and the precipitated mitochondria were suspended in a small volume of $0.3 \mathrm{M}$ sucrose, containing $10 \mathrm{~mm}$ phosphate buffer ( $\mathrm{pH} 7.2$ ), $10 \mathrm{mM} \mathrm{KCl}$ and $5 \mathrm{mM} \mathrm{MgCl}_{2}$. All operations were carried out between $\mathrm{O}$ and $4^{\circ} \mathrm{C}$.

Oxygen uptake. $\quad \mathrm{O}_{2}$ uptake was measured at $25^{\circ} \mathrm{C}$ in a $3-\mathrm{ml}$ sealed vessel using a Clark $\mathrm{O}_{2}$ electrode (Rank Brothers Co. Ltd.) as described by Estabrook. ${ }^{15)}$ The standard sequence of additions to the cuvette was as follows: $2.8 \mathrm{ml}$ of reaction medium, $0.1 \mathrm{ml}$ of mitochondrial fraction, $0.1 \mathrm{ml}$ of substrate $(1 \mathrm{~min}$ after mitochondria), and repeated additions each of $132 \mu \mathrm{M}$ of ADP. The reaction medium for the mitochodria contained: $0.3 \mathrm{M}$ mannitol, $10 \mathrm{mM} \mathrm{KCl}, 5 \mathrm{mM}$ $\mathrm{MgCl}_{2}$ and $10 \mathrm{~mm}$ potassium phosphate buffer ( $\mathrm{pH}$ 7.2). The $\mathrm{O}_{2}$ concentration in the air-saturated medium at $25^{\circ} \mathrm{C}$ was taken as $240 \mu \mathrm{M}$.

Split beam spectrophotometry. This was performed with a Union SM-401 spectrophotometer. The concentrations of the different Cyts were measured at room temperature from reduced minus oxidized difference spectra. Mitochondrial preparations were reduced with dithionite. The wavelengths selected for measurements and extinction coefficients were those given by Chance and Williams ${ }^{13)}$ and Lance and Bonner. ${ }^{17)}$

Extraction and determination of UQ. UQ was extracted following the method of Galliard et al. ${ }^{18)}$ The extract was disollved in $1 \mathrm{ml}$ of ethanol. In the case of the cell fractions from the protoplasts of BY-2 cells, the extract was further purified by TLC on a silica-gel plate with benzene as developing solvent. The quantity of UQ was determined by measuring the difference in absorbancy of oxidized and reduced UQ at $275 \mathrm{~nm}$. A $\Delta \varepsilon$ oxidized-reduced of 12.5 was used to determine the $\mu$ moles of UQ present. ${ }^{12)}$

Enzyme assay. Cyt c oxidase activity was determined by measuring the decrease of reduced Cyt $c$ at $550 \mathrm{~nm}$ according to the method of Nawa and Asahi. ${ }^{20}$ Fumarase activity was assayed by measuring the increase in absorbance at $240 \mathrm{~nm}$ following the method of Racker. ${ }^{21)}$ Catalase activity was assayed by measuring the disappearance of $\mathrm{H}_{2} \mathrm{O}_{2}$ at $240 \mathrm{~nm}$ following the method of Tolbert.22) Triosephosphate isomerase was coupled to glycerolphosphate dehydrogenase and followed by the oxidation of NADH at $340 \mathrm{~nm}$ following the method of Tolbert. ${ }^{22)}$

General methods. Protein concentration was estimated by the method of Lowry et al. ${ }^{23)}$, or the 
biuret procedure, ${ }^{24)}$ with BSA (Fraction V, Sigma Chemical Co. Ltd.) as standard.

\section{RESULTS AND DISCUSSION}

\section{Intracellular distribution of $U Q$ in $B Y-2$ cells}

The intracellular distribution of UQ in protoplasts from BY-2 cells is shown in Table I. The cell membrane debris fraction apparently brought down a large amount of mitochondrial particles as indicated by the relatively high amount of UQ and high Cyt $c$ oxidase activity in the $250 \times g$ fraction. UQ is concentrated in the $250 \sim 1000 \times g$ and $1000 \sim 10,000 \times g$ particles, and its distribution is well correlated with the distribution of Cyt $c$ oxidase activity in the particles. The relatively high level of UQ compared to Cyt $c$ oxidase activity in the soluble (supernatant) and microsomal fraction $(10,000 \sim 100,000 \times g$ pellet $)$ of the cells is consistent with the report by Leonhäuser et al..$^{25}$ ) who found UQ in animal tissue microsomes. These fractions could have some mitochondrial fragments, however, as similar results were obtained with spinach leaves by Crane. ${ }^{11,12\}}$ These results suggest that most of the UQ in BY-2 cells is also localized in the mitochondria, but not in the cytoplasm fraction in which most of UQ is localized in the hydrocarbon assimilating yeast.

\section{The activity of $B Y-2$ cell mitochondrial prepa-} rations

In order to avoid disintegration of organella, BY-2 cells were ruptured in a glass homogenizer. A satisfactory preparation of mitochondria was obtained from 5-day-old cells in the exponential phase rather than 7-day-old cells in the stationary phase. Mitochondria with excellent oxidation and phosphorylation capacities were obtained using the grinding medium supplemented either with a 5-fold amount of BSA or with $0.5 \%$ of PVP. Respiratory activity is shown in Fig. 1 which shows several oxygen electrode traces obtained from BY-2 cell preparations. Table II give the average values for rate of oxidation, ADP: $O$ ratios and respiratory control indices with succinate, malate and NADH as substrates. In the case of cultured plant cells, mitochondrial preparations which show a high degree of both coupling and respiratory control have only been prepared from Acer pseudoplatanus L. cells. ${ }^{26 \sim 28)}$ Inspection of Fig. 1 and Table II shows that the quality of the mitochondrial preparations is similar to that of other plants sources ${ }^{20,29 \sim 34)}$ and Acer pseudoplatanus cells. ${ }^{26 \sim 28)}$

\section{Purification of mitochondria}

Since, the protecting agent, PVP has an inhibitory effect on the separation of mitochondria from microbodies in sucrose isopicric centrifugation (M. Esaka and T. Asahi, personal communication), it was not added to the grinding medium for purification of mitochondria.

Figure 2 shows the sedimentation profiles of the mitochondrial preparation from BY-2 cells after sucrose density gradient centrifugation. Fumarase activity for the mitochondrial matrix marker is distributed in a peak at a density of $1.20 \mathrm{~g} / \mathrm{cm}^{3}$ with a shoulder centered around $1.18 \mathrm{~g} / \mathrm{cm}^{3}$ on the top side of the peak. Cyt $c$

Table I. Fractionation by Differential Centrifugation of the Protoplasts Isolated From BY-2 Cells and Distribution of UQ and Cyt $c$ Oxidase Activity

\begin{tabular}{|c|c|c|c|c|c|}
\hline \multirow[b]{2}{*}{ Fraction } & \multicolumn{2}{|c|}{$\overline{\mathrm{UQ}}(\mathrm{nmol})$} & \multicolumn{2}{|c|}{ Cyt $c$ oxidase $(\mu \mathrm{mol} / \mathrm{min})$} & \multirow{2}{*}{$\begin{array}{l}\text { Total (mg) } \\
\text { protein }\end{array}$} \\
\hline & $\begin{array}{l}\text { Total }(\%) \\
\text { amount }\end{array}$ & $\begin{array}{l}\text { pre } m g \\
\text { protein }\end{array}$ & $\begin{array}{l}\text { Total }(\%) \\
\text { activity }\end{array}$ & $\begin{array}{l}\text { per mg } \\
\text { protein }\end{array}$ & \\
\hline $0 \sim 250 \times g$ & $54.9(26.6)$ & 0.9 & $11.1(28.9)$ & 0.19 & 60 \\
\hline $250 \sim 1000 \times g$ & $71.3(34.6)$ & 2.1 & $14.6(38.0)$ & 0.43 & 34 \\
\hline $1000 \sim 10,000 \times g$ & $61.6(29.9)$ & 3.1 & $12.1(31.5)$ & 0.61 & 20 \\
\hline $10,000 \sim 100,000 \times \mathrm{g}$ & $8.7(4.2)$ & 0.9 & $0.6(1.6)$ & 0.06 & 10 \\
\hline Supernatant & $9.6(4.7)$ & 0.1 & $0.0(0.0)$ & 0.00 & 80 \\
\hline
\end{tabular}

Protein content was estimated by the biuret procedure. 


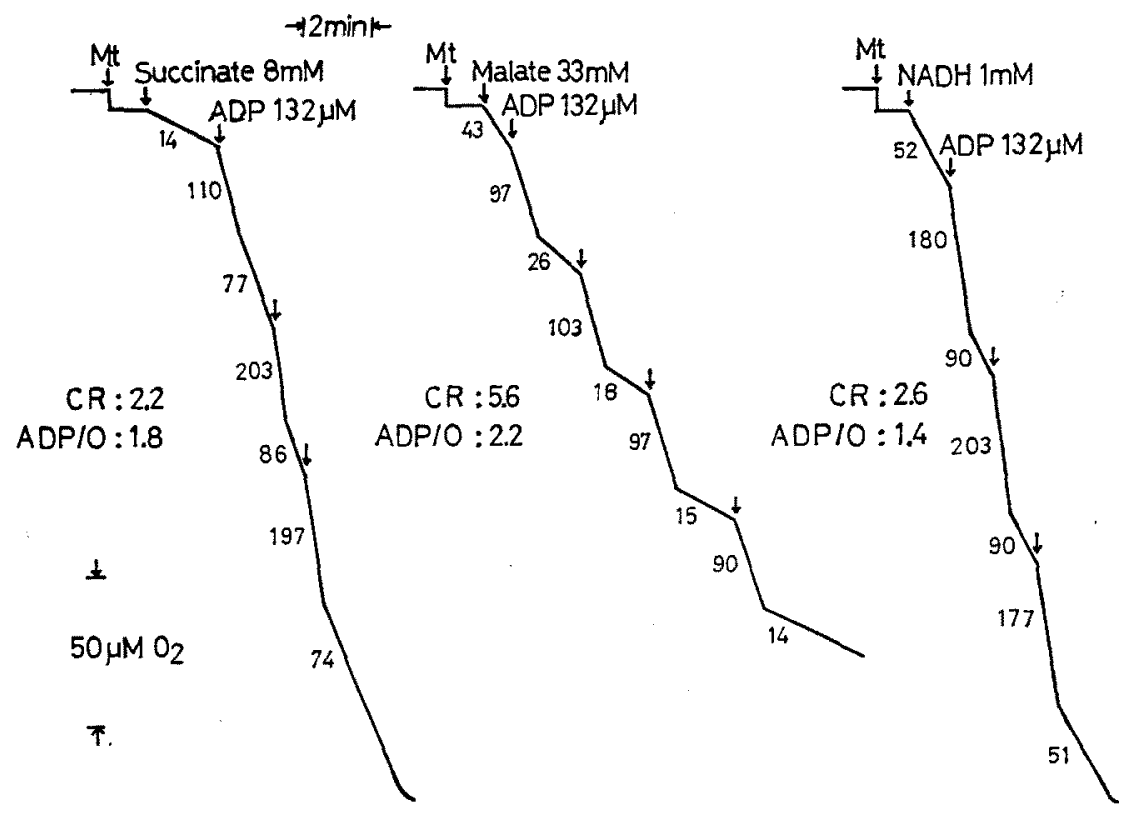

Frg. 1. Oxidation of Succinate, Malate and NADH by BY-2 Cell Mitochondria.

Concentrations given are final concentrations in reaction medium. Numbers on traces refer to $\mathrm{nmol}_{2}$ consumed $/ \mathrm{min} \cdot \mathrm{mg}$ mitochondrial protein. CR: respiratory control index. Protein content was estimated by the biuret procedure. The grinding medium supplemented with $0.5 \%$ of PVP was used for preparation of mitochondria.

Table II. Oxidation and Phosphorylation Capacities of BY-2 Cell Mitochondria

\begin{tabular}{lccc}
\hline \multicolumn{1}{c}{ Substrate } & $\begin{array}{c}\text { State } 3 \text { rates, nmoles } \\
\mathrm{O}_{2} \cdot \mathrm{min}^{-1} \cdot \mathrm{mg}^{-1} \text { protein }\end{array}$ & $\begin{array}{c}\text { Respiratory } \\
\text { control }\end{array}$ & ADP: O \\
\hline Succinate $(8 \mathrm{mM})$ & $153 \pm 47$ & $2.23 \pm 0.54$ & $1.55 \pm 0.13$ \\
Malate $(33 \mathrm{mM})$ & $74 \pm 16$ & $4.28 \pm 1.00$ & $2.18 \pm 0.08$ \\
NADH $(1 \mathrm{mM})$ & $140 \pm 31$ & $2.95 \pm 0.61$ & $1.38 \pm 0.08$ \\
\hline
\end{tabular}

Data are averages \pm S.D. of 5 experiments with $0.5 \%$ of PVP in the grinding medium.

Protein content was estimated by the biuret procedure.

oxidase as a mitochondrial membrane marker was distributed in a peak at a density of $1.20 \mathrm{~g} / \mathrm{cm}^{3}$ which corresponded to that of fumarase activity. There was an additional peak of Cyt $c$ oxidase activity at a lighter position, the density of which $\left(1.18 \mathrm{~g} / \mathrm{cm}^{3}\right)$ was coincident with that of the shoulder of fumarase activity. Triosephosphate isomerase as proplastids or etioplasts was distributed over a single broad density range about $1.18 \mathrm{~g} / \mathrm{cm}^{3}$ and with a considerable amount of solubilized activity in the supernatant fluid. Catalase activity for microbodies was found in the most dense regions of the gradient around $1.21 \mathrm{~g} / \mathrm{cm}^{3}$. A major protein band in the gradient can be seen to corres- pond in position and profile to fumarase activity. It is uncertain whether the light density mitochondria are disintegrated or natively different from the heavy ones.

Figure 3 shows a sedimentation profile of the mitochondrial preparation from mung bean seedlings, which indicates the presence of two different density mitochondria. Contrary to the case of BY-2 cells, fumarase activity is mainly distributed in a peak at a density of $1.17 \mathrm{~g} / \mathrm{cm}^{3}$ with a shoulder centered around $1.18 \mathrm{~g} / \mathrm{cm}^{3}$ on the bottom side of the peak and Cyt $c$ oxidase was in a peak at a density of $1.17 \mathrm{~g} / \mathrm{cm}^{3}$. Triosephosphate isomerase was distributed over two density ranges of about 


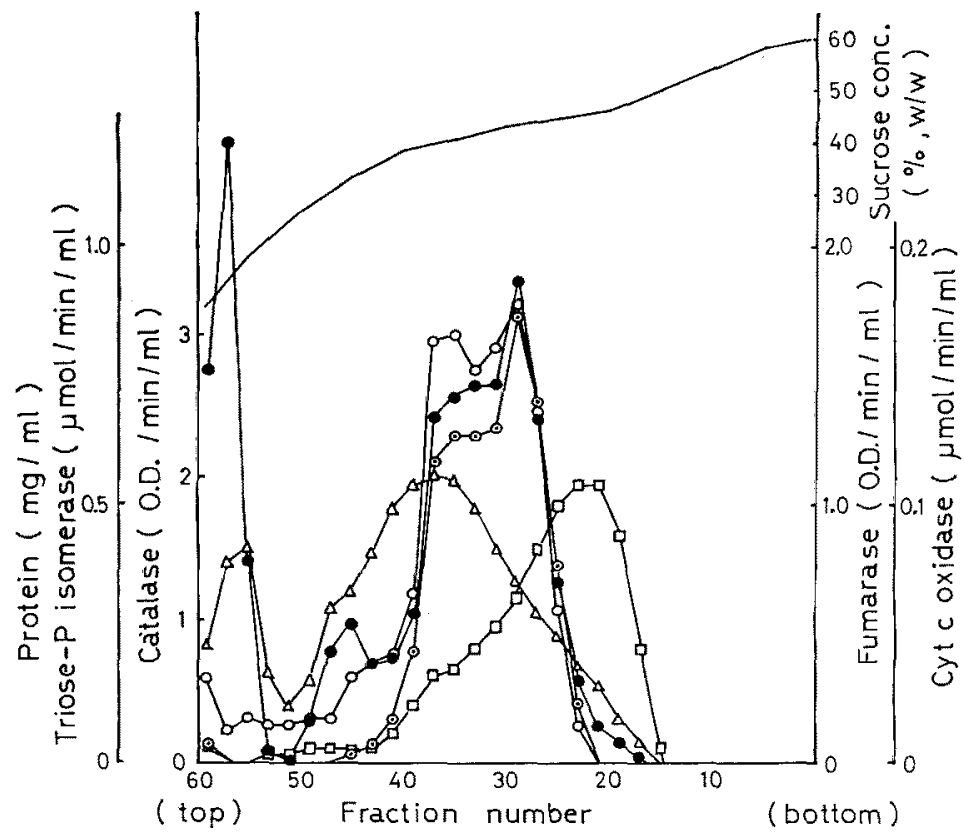

FIG. 2. Distribution of Enzyme Activities in the Separated Fractions after Sucrose Density Gradient Centrifugation of a Mitochondrial Preparation from BY-2 Cells.

Protein content was determined by the method of Lowry et al. Fumarase $(\odot-\odot)$; Cyt $c$ oxidase $(\bigcirc-O)$; catalase $(\square-\square)$; triosephosphate isomerase $(\Delta-\Delta)$; protein (

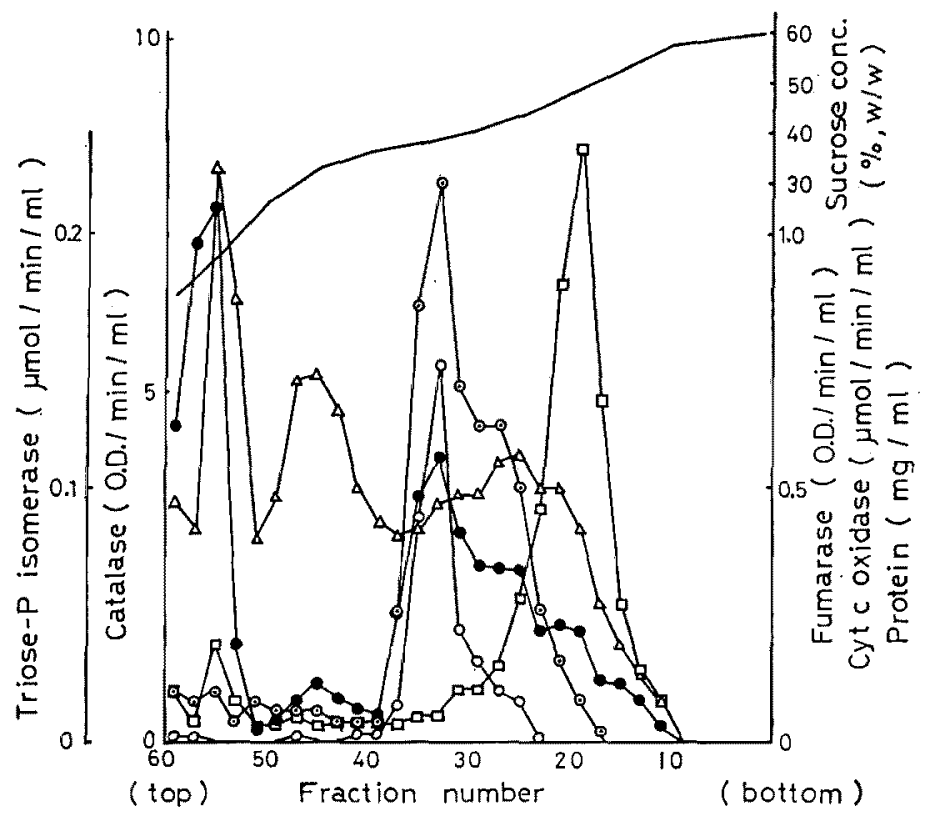

Fig. 3. Distribution of Enzyme Activities in the Separated Fractions after Sucrose Density Gradient Centrifugation of a Mitochondrial Preparation from Mung Bean Seedlings.

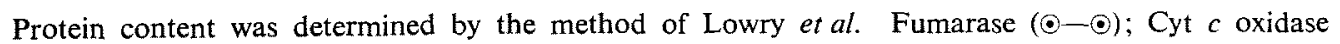
$(O-O)$; catalase $(\square-\square)$; triosephosphate isomerase $(\Delta-\Delta)$; protein 
1.19 and $1.14 \mathrm{~g} / \mathrm{cm}^{3}$ and with a considerable amount of solubilized activity in the supernatant fluid. The catalase activity was found around $1.22 \mathrm{~g} / \mathrm{cm}^{3}$. A major protein band in the gradient can be seen to correspond in position and profile to fumarase activity and thus represents the mitochondrial component.

\section{Quantitative determination of Cyts in purified} mitochondria

As purified mitochondria fractions, 25 32 (heavier one) and $31 \sim 37$ were employed for BY-2 cells and mung bean hypocotyls, respectively, because there were no spectral diferences between the two different density mitochondrial fractions.

Figure 4 shows the room temperature difference spectra obtained with mitochondria from BY-2 cells and mung bean hypocotyls. The two spectra show clear identification of the Cyt after reduction of the mitochondrial prepa- ration by dithionite. In the case of $\mathrm{BY}-2$ cell mitochondria, the $\alpha$ band of Cyt $a a_{3}$ is located at $606 \mathrm{~nm}$, the $\alpha$ band of Cyt $c$ at $554 \mathrm{~nm}$, and the $\alpha$ band of Cyt $b$ appears as a shoulder centered around $562 \mathrm{~nm}$. The Soret region is dominated by the peak of Cyt $b$ at $428 \mathrm{~nm}$, whereas Cyt $a a_{3}$ appears as a small shoulder on the longer wavelength side of Cyt $b$. In the case of BY-2 cell mitochondria, we observed only a striking reduction of the Cyt $a a_{3}$ peaks (606 and $445 \mathrm{~nm}$ ). In the case of mung bean hypocotyl mitochondria (Fig. 4), the $\alpha$ band of Cyt $a a_{3}$ is located at $606 \mathrm{~nm}$, the $\alpha$ band of Cyt $b$ at $562 \mathrm{~nm}$, and the $\alpha$ band of Cyt $c$ appears as a shoulder centered around $554 \mathrm{~nm}$. The Soret region is dominated by the absorption peak of Cyt $b$ at $428 \mathrm{~nm}$, whereas Cyt $a a_{3}$ appears as a shoulder centered around $445 \mathrm{~nm}$. These observations are in good agreement with those of Douce et al. ${ }^{29}$ )

The concentrations of the various electron

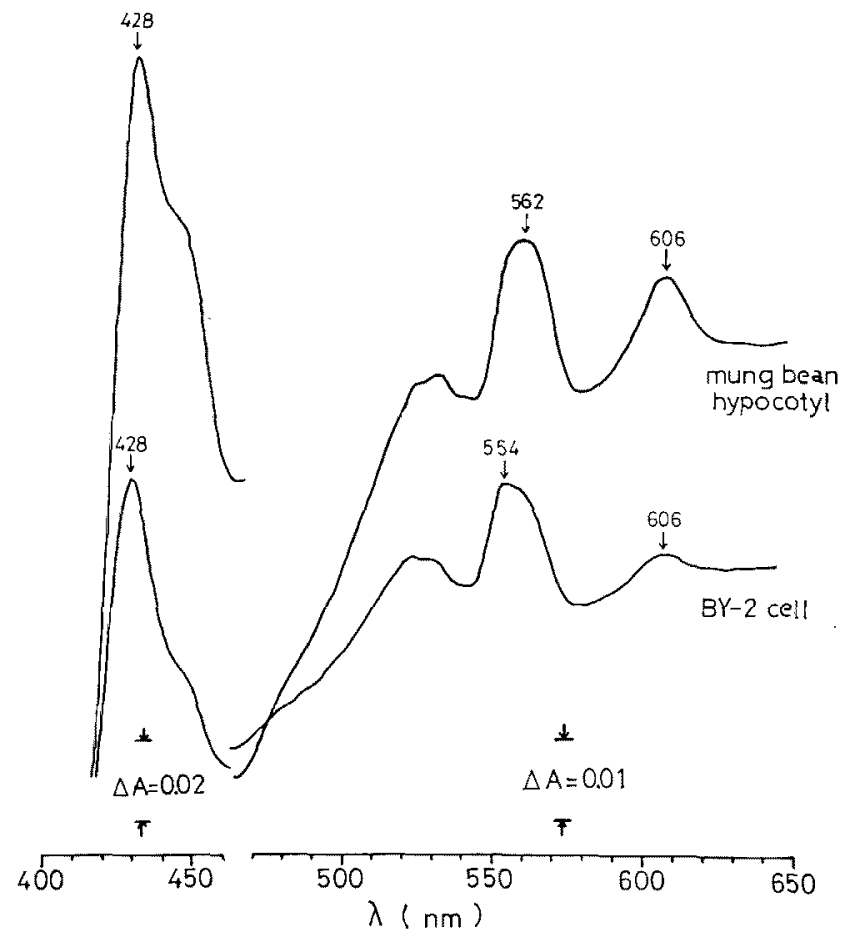

FIG. 4. Difference Spectra of Purified Mitochondria at Room Temperature $\left(25^{\circ} \mathrm{C}\right)$.

Dithionite reduced minus aerobic. Mitochondria were suspended in the medium containing: $0.3 \mathrm{M}$ sucrose, $10 \mathrm{mM} \mathrm{KCl}, 5 \mathrm{~mm} \mathrm{MgCl}$ and $10 \mathrm{~mm}$ potassium phosphate buffer (pH 7.2). Optical path: $10 \mathrm{~mm}$. Mitochondrial protein: BY-2 cell, $1.8 \mathrm{mg} / \mathrm{ml}$; mung bean hypocotyl, $2.1 \mathrm{mg} / \mathrm{ml}$. Protein concentration was determined by the method of Lowry et al. 
Table III. Concentration and Molar Ratio of Respiratory Chain Components in PuRIFIEd Mitochondria

\begin{tabular}{lccccc}
\hline \multirow{2}{*}{ Material } & \multicolumn{5}{c}{$\begin{array}{c}\text { Carrier concentration nmol/mg-protein } \\
\text { (Relative concentration) }\end{array}$} \\
\cline { 2 - 5 } & Cyt $a a_{3}$ & Cyt $b$ & Cyt $c$ & Fp & UQ \\
\hline BY-2 cells & 0.08 & 0.40 & 0.37 & 0.78 & 7.1 \\
& $(0.22)$ & $(1.08)$ & $(1.00)$ & $(2.11)$ & $(19.2)$ \\
Mung bean & 0.25 & 0.47 & 0.42 & 1.34 & 6.9 \\
hypocotyls & $(0.60)$ & $(1.12)$ & $(1.00)$ & $(3.19)$ & $(14.4)$ \\
\hline Reference $\lambda$ used $(\mathrm{nm})$ & 630 & 575 & 540 & 510 & \\
Measuring $\lambda$ used $(\mathrm{nm})$ & 606 & 562 & 554 & 465 & \\
$\varepsilon\left(\mathrm{mM}^{-1} \mathrm{~cm}^{-1}\right)$ & 16.5 & 17.9 & 19.1 & 11.0 & \\
\hline
\end{tabular}

Protein concentration was estimated by the method of Lowry et al.

carriers, obtained by using the method of Chance and Williams ${ }^{16)}$ for two different kinds of mitochondria, are given in Table III. Expressed in terms of nmols per $\mathrm{mg}$ of mitochondrial protein, the concentrations of the different Cyts are similar to the concentrations generally found in plant mitochondria. ${ }^{1729}$ ) The concentrations of the $b$ - and $c$-type Cyts in BY-2 cell mitochondria appear to be similar to those in mung bean hypocotyl mitochondria. However, the Cyt $a a_{3}$ content in BY-2 cell mitochondria is significantly lower than that in mung bean hypocotyl mitochondria. When expressed on a relative basis (Table III), taking the Cyt $c$ concentration as the unity, the stoichiometry of the different electron carriers found in BY-2 cell mitochondria and mung bean hypocotyl mitochondria is similar to that reported for plant tissues ${ }^{17,29)}$ and Acer pseudo-

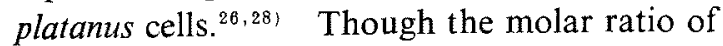
Cyt $a a_{3}$ in BY-2 cell mitochondria seems to be relatively lower. Bligny and Douce ${ }^{28)}$ reported that the concentration of the Cyt $a a_{3}$ is dramatically lower in the mitochondria from copper-deficient Acer pseudoplatanus cells. In contrast, the $b$ - and $c$-type Cyts contents of the sycamore mitochondria are invariable on copper depletion. The media to obtain copperdeficient cells and normal sycamore cells contained 0.5 and $25 \mu \mathrm{g}$ of copper/liter, respectively. In our experiment, Murashige-Skoog inorganic medium $^{36}$; containing $6.4 \mu \mathrm{g}$ of copper $\left(25 \mu \mathrm{g} \mathrm{CuSO}_{4} \cdot 5 \mathrm{H}_{2} \mathrm{O}\right) /$ liter was used as the basal medium. With this condition, it is likely that the striking reduction in the Cyt $a a_{3}$ content in BY-2 cell mitochondria is attributable to the copper deficiency.

UQ content and its molar ratio to the electron transport components in purified mitochondria The concentration of UQ in the mitochondria isolated from cultured plant cells has not been investigated at all. The UQ contents and the molar ratio of UQ to other electron transport components in the purified mitochondria are shown in Table III. On a protein basis, the UQ content of BY-2 cell mitochondria is similar to that of mung bean hypocotyls. Pumphrey and Redfearn reported that the spadix of Arum maculatum, an active nonphotosynthetic tissue, contains $1.4 \mu$ moles of UQ per $\mathrm{g}$ of mitochondrial protein. ${ }^{367}$ Beyer et al. reported that the concentration of UQ in the submitochondrial particles from etiolated mung bean (Phaseolus aureus) seedlings is of the order of $4.4 \mathrm{nmol}$ per $\mathrm{mg}$ particle protein, approximately equal to that found in similar submitochondrial particles from beef heart. ${ }^{13}$ In the case of animal tissues, the UQ contents in beef heart muscle and rat liver mitochondria are $3.4 \sim 4.0 \mathrm{nmol}$ and $1.7 \mathrm{nmol}$ per $\mathrm{mg}$ protein, respectively. ${ }^{37}$ So the UQ content in BY-2 cell mitochondria seems to be not much higher than other living cell mitochondria.

The molar ratio of UQ to the other electron carriers in BY-2 cell mitochondria is also similar to that in mung bean hypocotyl mitochondria. It seems that the molar ratio of UQ to other electron transport components in 
BY-2 cell mitochondria is not so high compared with that in other plant mitochondria. These ratios are similar to that in the mitochondria of a hydrocarbon assimilating yeast (Candida tropicalis pK 233), ${ }^{10}$ though $2.3 \sim$ 3.4 times higher than those in animal mitochondria. ${ }^{38}$

Acknowledgments. The authors wish to express their thanks to Dr. T. Asahi, the University of Nagoya, Dr. K. Momose, the University of Kanazawa, and Drs K. Nakata and S. Iwai of our institute for their kind suggestions and useful advice.

\section{REFERENCES}

1) T. Ikeda, T. Matsumoto, K. Kato and M. Noguchi, Agric. Biol. Chem., 38, 2297 (1974).

2) T. Ikeda, T. Matsumoto and M. Noguchi, Phytochemistry, 15, 568 (1976).

3) T. Ikeda, T. Matsumoto and M. Noguchi, Agric. Biol. Chem., 40, 1765 (1976).

4) T. Ikeda, T. Matsumoto and M. Noguchi, Agric. Biol. Chem., 41, 1197 (1977).

5) T. Ikeda, T. Matsumoto and M. Noguchi, Phytochoemistry, 17, 1879 (1978).

6) W. T. Griffiths, D. R. Threlfall and T. W. Goodwin, European J. Biochem., 5, 124 (1968).

7) F. L. Crane, "Biochemistry of Quinones," ed. by R. A. Morton, Academic Press, London and New York, 1965, p. 183.

8) A. C. Page, P. Gale, H. Wallick, R. B. Walton, L. E. McDaniel, H. B. Woodruff and K. Folkers, Arch. Biochem. Biophys., 89, 318 (1960).

9) N. M. Pacter and J. Glover, Biochim. Biophys. Acta, 58, 531 (1962).

10) A. Tanaka, S. Shimizu and S. Fukui, J. Ferment. Technol, 52, 925 (1974).

11) F. L. Crane, Plant Physiol., 34, 128 (1959).

12) R. A. Dilley and F. L. Crane, Plant Physiol., 38, 452 (1963).

13) R. E. Beyer, G. A. Peters and H. Ikuma, Plant Physiol., 43, 1395 (1968).

14) W. D. Bonner, Jr., "Methods in Enzymology," Vol. X, ed. by R. W. Estabrook and M. E. Pullman, Academic Press, New York and London, 1967, p. 126.

15) R. W. Estabrook, "Methods in Enzymology,"
Vo. X, ed. by R. W. Estabrook and M. E. Pullman, Academic Press, New York and London, 1967, p. 41.

16) B. Chance and G. R. Williams, J. Biol. Chem., 217, 395 (1955).

17) C. Lance and W. D. Bonner, Jr., Plant Physiol., 43, 756 (1968).

18) T. Galliard, R. H. Michell and J. N. Hawthorne, Biochim. Biophys. Acta, 106, 551 (1965).

19) F. L. Crane and R. Barr, "Methods in Enzy. mology," Vol. XVIII, ed. by D. B. McCormick and L. D. Wright, Academic Press, New York and London, 1971, p. 137.

20) Y. Nawa and T. Asahi, Plant Physiol., 48, 671, (1971).

21) E. Racker, Biochim. Biophys. Acta, 4, 211 (1950).

22) N. E. Tolbert, "Methods in Enzymology," Vol. XXXI, ed. by S. Fleischer and L. Packer, Academic Press, New York and London, 1974, p. 734.

23) O. H. Lowey, N. J. Rosebrough, A. L. Farr and R. J. Randall, J. Biol. Chem., 193, 265 (1951).

24) A. G. Gornal, C. S. Bardawill and M. M. David, J. Biol. Chem., 177, 751 (1949).

25) S. Leonhäuser, K. Leybold, K. Krisch, Hj. Staudinger, P. H. Gale, A. C. Page, Jr. and K. Folkers, Arch. Biochem. Biophys., 96, 580 (1962).

26) S. B. Wilson, J. Exper. Botany, 22, 725 (1971).

27) R. Bligny and R. Douce, Physiol. Vég., 14, 499 (1976).

28) R. Bligny and R. Douce, Plant Physiol, 60, 675 (1977).

29) R. Douce, E. L. Christensen and W. D. Bonner, Jr., Biochim. Biophys. Acta. 275, 148 (1972).

30) H. Ikuma and W. D. Bonner, Jr., Plant Physiol., 42, 67 (1967).

31) H. S. Ku, H. K. Pratt, A. R. Spurr and W. M. Harris, Plant Physiol., 43, 883 (1968).

32) I. V. Sarkissian and H. K. Srivastava, Plant Physiol., 43, 1406 (1968).

33) H. Ikuma, Plant Physiol, 45, 773 (1970).

34) M. Greksak, T. Asahi and I. Uritani, Plant \& Cell Physiol., 13, 1117 (1972).

35) T. Murashige and F. Skoog, Physiol. Plant., 15, 473 (1962).

36) A. M. Pumphrey and E. R. Redfearn, Biochem. $J ., 76,61$ (1960).

37) R. L. Lester and F. L. Crane, J. Biol. Chem., 234, 2169 (1959).

38) D. E. Green and D. C. Wharton, Biochem. Z., 338, 335 (1963). 